\title{
Key habitat features facilitate the presence of Barred Owls in developed landscapes
}

\author{
Marion A. Clement ${ }^{1}$, Kyle Barrett ${ }^{1}$ and Robert F. Baldwin ${ }^{1}$ \\ ${ }^{1}$ Department of Forestry and Environmental Conservation, Clemson University, Clemson, South Carolina, USA
}

\begin{abstract}
As urbanization continues to transform landscapes, it is imperative to find ways to conserve biodiversity within fragmented habitats. Forest interior dwelling birds are particularly vulnerable to development pressures because they require large tracts of forest to support their life cycles. Although Barred Owls (Strix varia) are frequently described as an obligate mature forest species, they have been found in urbanized landscapes. To determine if certain habitat characteristics, such as mature trees, facilitate the presence of Barred Owls in developed regions, we modeled Barred Owl occupancy probability along a development gradient in the Piedmont region of the southeastern United States. We surveyed for owls by broadcasting conspecific calls to solicit response and by passively recording at survey sites using autonomous recording units. Detection/nondetection data were collected during the breeding season and analyzed within an occupancy framework to investigate patterns of habitat association in our region, while allowing for imperfect detection of owls. Average tree height was the best predictor of Barred Owl occupancy across a development gradient, regardless of forest coverage. We did not find Barred Owl occupancy to decline with increasing impervious surface density. Our research implies that developed landscapes containing mature urban trees can support breeding populations of Barred Owls.
\end{abstract}

\section{Des caractéristiques clés d'habitat facilitent la présence de Chouettes rayées dans les paysages urbanisés}

RÉSUMÉ. L'urbanisation transformant en continu les paysages, il est impératif de trouver des façons de conserver la biodiversité dans les milieux fragmentés. Les oiseaux qui fréquentent l'intérieur des forêts sont particulièrement vulnérables à l'étalement urbain parce qu'ils ont besoin de grands parterres forestiers durant leur cycle annuel. Bien que les Chouettes rayées (Strix varia) soient souvent décrites comme des espèces de forêts matures strictes, elles ont pourtant aussi été trouvées dans des paysages urbanisés. Afin de déterminer si certaines caractéristiques de l'habitat, tels que les arbres matures, facilitaient la présence de chouettes dans les régions urbanisées, nous avons modélisé la probabilité d'occurrence de cette espèce le long d'un gradient d'urbanisation dans la région du Piedmont dans le sud-est des États-Unis. Nous avons inventorié les chouettes en diffusant des enregistrements de chants de conspécifiques afin de susciter une réponse, et passivement, en enregistrant au moyen d'enregistreurs automatisés à des sites d'inventaire. Les données de détection/non-détection ont été récoltées durant la saison de nidification et analysées dans le contexte d'un modèle d'occurrence pour investiguer les tendances dans l'association espèce-habitat dans la région, tout en tenant compte de la détection incomplète des chouettes. La hauteur moyenne des arbres s'est avérée la variable la meilleure pour prédire la présence des Chouettes rayées le long d'un gradient d'urbanisation, peu importe le couvert forestier. Nous n'avons pas observé de diminutions dans la présence des chouettes avec l'augmentation de la densité de superficie imperméable. Notre étude indique que les paysages urbanisés qui comportent des arbres matures peuvent accueillir des populations nicheuses de Chouettes rayées.

Key Words: Barred Owl; habitat selection; occupancy modeling; Strix varia; urbanization; urban wildlife

\section{INTRODUCTION}

As urbanization continues to transform landscapes, habitat fragmentation has become a priority concern in wildlife conservation. The ecological implications of urbanization extend beyond urban cores. Urbanization drives land conversion at the periphery of cities (Brown et al. 2005), reduces forest patch size (Medley et al. 1995), contaminates water resources (Arnold and Gibbons 1996, Wang et al. 2001), and results in decreased habitat and species richness (McKinney 2002). Fragmentation in the forest mosaic has been shown to reduce avian diversity, particularly in forest interior birds (Kluza et al. 2000, Hepinstall et al. 2008). Raptors can be sensitive to habitat fragmentation because they require large patches of habitat containing diverse prey (Bosakowski and Smith 1997). However, a number of studies suggest that some raptors can thrive in urban settings, particularly predators of small mammals and birds commonly associated with development (Estes and Mannan 2003, Chace and Walsh 2006, Rullman and Marzluff 2014, Millsap 2018).

The Barred Owl (Strix varia) is described as requiring contiguous mature forest (Johnsgard 2002, Livezey 2007) and has been used as an indicator species for forest health (McLaren et al. 1998, Hess and King 2002, U.S. Department of Agriculture 2004). As the Barred Owl exhibits high interannual territorial fidelity (as reviewed in Johnsgard 2002), territories must meet the species' requirements throughout its life cycle. Barred Owl habitat requirements include dense overstory canopy for thermoregulation 
and daytime protection from mobbing, large trees with natural cavities for nesting, and an open understory that provides unobstructed flight paths and exposed prey (Nicholls and Warner 1972, Haney 1997, Livezey 2007). Although Barred Owls use both upland and lowland habitats, evidence exists that aquatic features such as riparian areas offer abundant prey and nest cavities (Livezey 2007, Wiens et al. 2014). Many of the habitat requirements for Barred Owls are typical of contiguous mature forest; thus the species is most often found far from development. In two comparative studies, Barred Owls were shown to avoid human activity more than buteo hawks, Great Horned Owls (Bubo virgianus), and Eastern Screech Owls (Otus asio; Bosakowski and Smith 1997) and had stronger negative associations with forest fragmentation than Great Horned Owls (B. virgianus) and Northern Saw-whet Owls (Aegolius acadicus; Grossman et al. 2008).

Despite extensive accounts in the literature that Barred Owls prefer contiguous mature forest, several studies have described this species occupying cities in the United States such as Charlotte, North Carolina (Harrold 2003), and Cincinnati, Ohio (Dykstra et al. 2012); suburbs within Seattle, Washington (Rullman and Marzluff 2014); and the greater Vancouver region in Canada (Hindmarch and Elliott 2015). In Charlotte, studies of prey items, fledging survival, and dispersal rates demonstrate that wooded suburban landscapes are supporting a local population of Barred Owls (Harrold 2003, Mason 2004, Cauble 2008). The birds in this population have higher reproductive success than their forested counterparts (Mason 2004), which may be attributable in part to dietary subsidies of birds and small mammals attracted to bird feeders (Cauble 2008). The concept that Barred Owls select for both mature contiguous forest and wooded suburbs seems paradoxical. Researchers have speculated that older wooded suburbs share similar habitat structure as mature forest, such as open understory and large street trees (Harrold 2003, Bierregaard 2018; Fig. 1). Despite these similarities, it is evident that these two types of habitat also provide very different resources to owls, such as prey species available and unique foraging opportunities such as bird feeders and koi ponds (Harrold 2003, Cauble 2008).

We used an occupancy framework (Mackenzie et al. 2002) to investigate the habitat associations of Barred Owls along a development gradient in the Piedmont region of the southeastern United States. We hypothesized that factors related to habitat, as well as the amount of human development, would influence Barred Owl occupancy across our surveyed landscape. Habitat variables included types of forest cover, tree height, and aquatic features, and development was assessed from percent impervious surface (Table 1).

\section{METHODS}

\section{Study area}

We conducted surveys along an urban-wildland gradient within a $300 \mathrm{~km}^{2}$ portion of the Piedmont ecoregion of South Carolina (Fig. 2). Development in the region is driven by proximity to the regional cities of Greenville and Anderson, South Carolina, as well as the large greater metropolitan areas of Charlotte, North Carolina, and Atlanta, Georgia. Several small towns (population size range 3000-13,000) in Anderson, Oconee, and Pickens Counties were used as the focal area for sampling prospective
Barred Owl habitat in developed areas. These towns are in close proximity to a large forested tract, the Clemson Experimental Forest (CEF), which includes 7082 ha of forest. A portion of the CEF is harvested annually and planted with loblolly pine (Pinus taeda), but the majority is recovering hardwood (oak-hickory stands) and native pine forest, used primarily for education and recreation. The CEF is the largest contiguous block of forest within $20 \mathrm{~km}$; the remaining landscape matrix is composed of agriculture, smaller forest blocks, and residential development. Our study region is estimated to have undergone a $22.5 \%$ population increase since 2010 (U.S. Census Bureau, http://www. census.gov/quickfacts/clemsoncitysouthcarolina); this context offered a range of development densities and neighborhood ages that could be leveraged to assess Barred Owl presence across a range of urban habitat structures.

Table 1. Continuous site variables used in occupancy models of Barred Owl (Strix varia) habitat associations in the Piedmont of South Carolina. All variables were measured within $400 \mathrm{~m}$ radius buffers centered on the survey points. Cover variables were converted to percentages by dividing the summary value by the buffer area $\left(\sim 0.5 \mathrm{~km}^{2}\right)$. Buffer area represents the average territory size for male Barred Owls in our region (Clement, Barrett, and Baldwin, unpublished data). DNR, Department of Natural Resources; LiDAR, light detection and ranging.

\begin{tabular}{|c|c|c|c|}
\hline Variables & Units & Description & Data Source \\
\hline DECID & $\%$ & $\begin{array}{l}\text { Deciduous forest cover; } \\
\text { owls may select for it. }\end{array}$ & $\begin{array}{l}\text { Supervised classification } \\
\text { of aerial imagery }\end{array}$ \\
\hline CONIF & $\%$ & $\begin{array}{l}\text { Coniferous forest cover; } \\
\text { owls may avoid it. }\end{array}$ & $\begin{array}{l}\text { Supervised classification } \\
\text { of aerial imagery }\end{array}$ \\
\hline TREE & $\mathrm{m}$ & Average tree height; & $2011 \mathrm{LiDAR}$ and \\
\hline HEIGHT & & owls may select for it. & $\begin{array}{l}\text { supervised classification } \\
\text { forest }\end{array}$ \\
\hline IMPERV & $\%$ & $\begin{array}{l}\text { Impervious surface } \\
\text { cover; owls may avoid } \\
\text { it. }\end{array}$ & $\begin{array}{l}\text { Supervised classification } \\
\text { of aerial imagery }\end{array}$ \\
\hline WETLAND & $\%$ & $\begin{array}{l}\text { Wetland cover; owls } \\
\text { may select for it. }\end{array}$ & $\begin{array}{l}\text { National Wetland } \\
\text { Inventory }\end{array}$ \\
\hline STREAM & $\begin{array}{c}\mathrm{m} / \\
\mathrm{km}^{2}\end{array}$ & $\begin{array}{l}\text { Stream density (total } \\
\text { length in buffer); owls } \\
\text { may select for it. }\end{array}$ & $\begin{array}{l}\text { South Carolina DNR } \\
\text { hydrography }\end{array}$ \\
\hline
\end{tabular}

\section{Sampling sites}

Prior to generating survey points, we constrained the potential survey area to ensure survey efficiency and safety of personnel. First, we applied a minimum threshold of $40 \%$ canopy cover by raster cell (30-m resolution) across our study area using the National Land Cover Dataset (NLCD) 2011 U.S. Forest Service Tree Canopy data set (Homer et al. 2015). This threshold was intended to remove unsuitable habitat for owls such as open water, parking lots, and farmland. To specify this threshold, we extracted minimum NLCD canopy cover from 18 telemetry locations from an urban Barred Owl dispersal study in Charlotte, North Carolina, USA (Mason 2004). We justified applying data from Mason (2004) to this study because Charlotte is $190 \mathrm{~km}$ from our study region and is also located in the Piedmont province. We further limited our survey area by constraining it to Clemson University property or public property within $40 \mathrm{~m}$ of paved or forest roads. 
Avian Conservation and Ecology 14(2): 12

Fig. 1. Potential habitat characteristics important to Barred Owls (Strix varia) shared by mature forests and suburban environments. Illustration by Marion Clement.

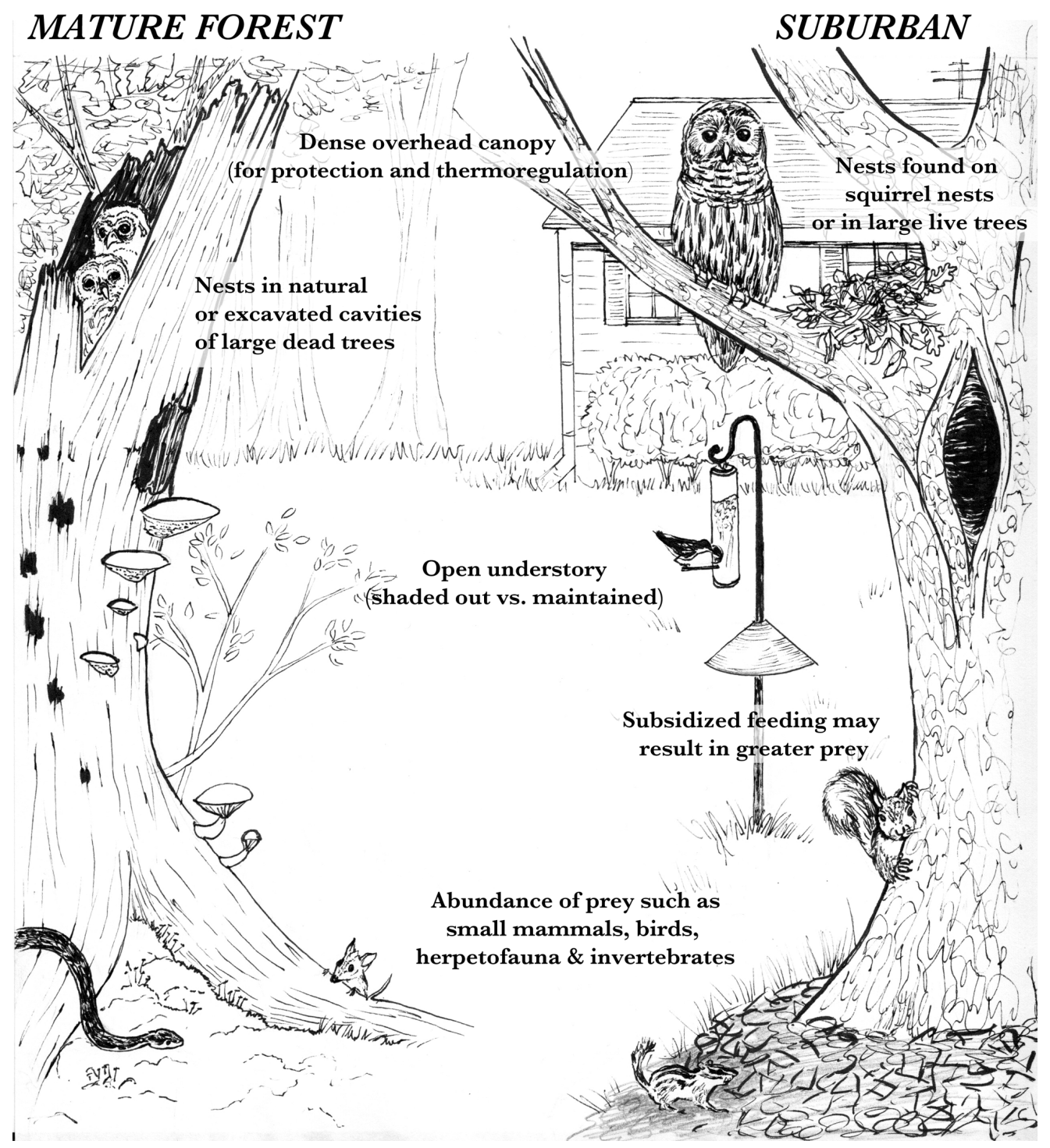

Within our study area, we used the Human Modification for North America data set (HM-T; modified from Theobald 2013; https://www.databasin.org) to define the development gradient (Fig. 2). This data set combines numerous anthropogenic ecological stressors, such as development, agriculture, and energy production, into a single index that accounts for both their intensity and footprint while minimizing bias associated with nonindependence of variables (Theobald 2013). The HM-T accounts for neighboring spatial and landscape attributes; it is a continuous index on a scale from 0 to 1 from complete forest cover to highly urbanized (230-m resolution). We categorized the HM$\mathrm{T}$ index into 5 equal bins of 0.20 increments for sampling design purposes.

To generate survey points, we overlaid a $40-\mathrm{m}$ point grid within our study area and attributed an HM-T class to each point. We used the R package "spsurvey" (Kincaid and Olsen 2016) and the generalized random tessellation stratified sampling method (Stevens and Olsen 2004) to generate 14 sites within each HM-T class $(n=70)$. Using random sampling, we further constrained sites to be a minimum of $800 \mathrm{~m}$ apart, while ensuring we retained a minimum of $35 \%$ of developed sites with HM-T $>0.40$. We considered $800 \mathrm{~m}$ between survey sites to be sufficient to sample different pairs of owls because preliminary GPS data from 12 males we tagged in spring 2019 suggests Barred Owl home ranges in our study region are an average of $0.5 \mathrm{~km}^{2}$ (> 300 locations per individual; Clement, Barrett, and Baldwin, unpublished data). Barred Owl territories in the Southeast are much smaller than in the northern and western United States (Odom and Mennill 2010, Bierregaard 2018), and owl territories in developed landscapes are substantially smaller than territories in rural areas (Bierregaard 2018). Using the minimum distance and HM-T threshold described previously, we removed 22 sites and retained 
Fig. 2. We surveyed 48 sites in spring 2018 for Barred Owls (Strix varia) in the Clemson, South Carolina, area. Sites were distributed along a development gradient defined by the Human Modification for North America model (HM-T; Theobald 2013). The Clemson Experimental Forest (CEF) contained most of the densely forested sites.

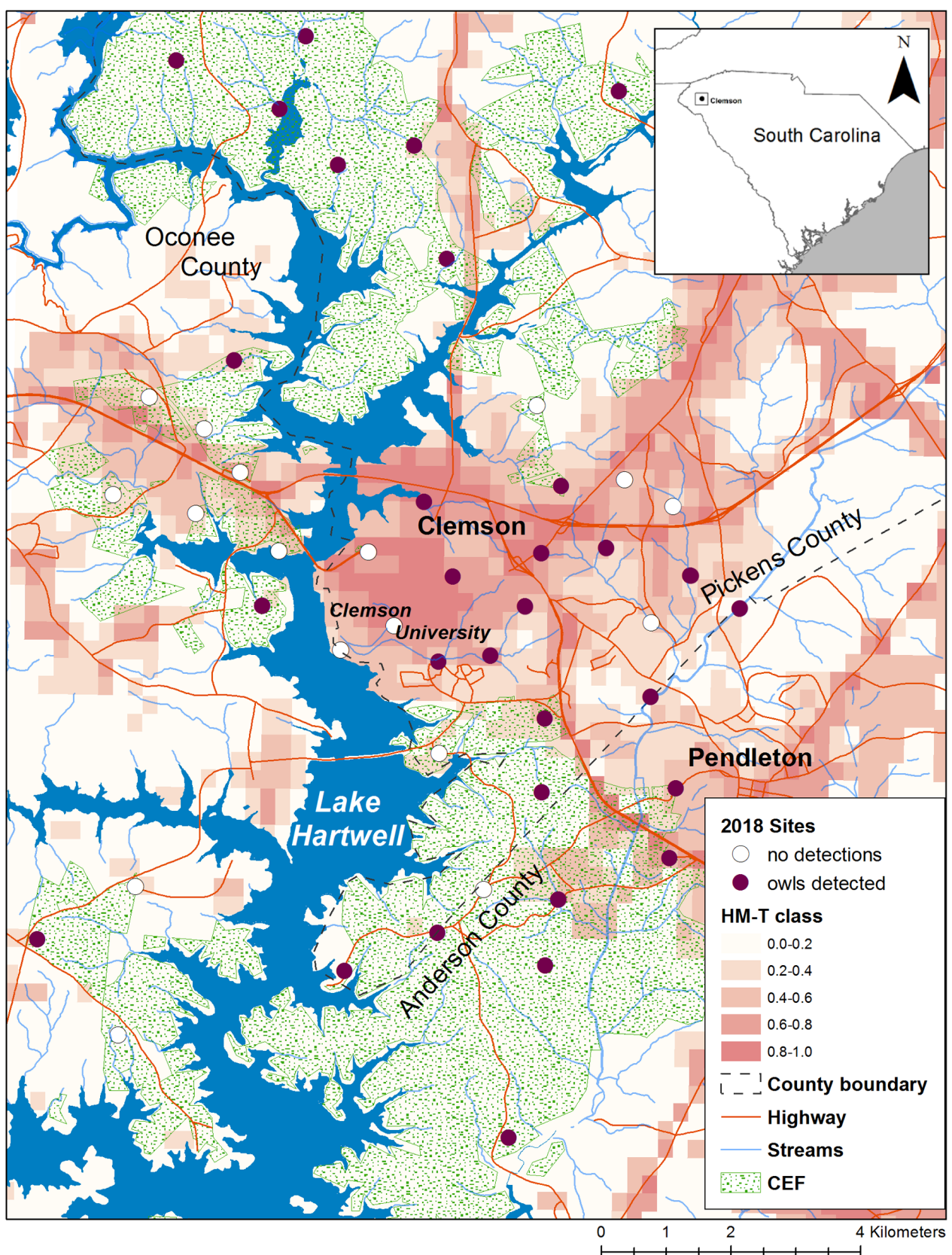

48 sites (Fig. 2). Because of the rural nature of the study region, the final distribution of sites was slightly skewed toward low development; $58 \%$ of sites had an HM-T $\leq 0.40$, and rural sites were more dispersed than urban sites. The CEF contained most of the sites that were either densely forested or had low development.

We used a $400 \mathrm{~m}$ radius buffer centered on the survey points as a sampling unit because it represents the average territory of a breeding male Barred Owl in our region $\left(\sim 0.5 \mathrm{~km}^{2}\right.$; Clement, Barrett, and Baldwin, unpublished data). This optimized the likelihood of estimating habitat characteristics directly associated with the owl's home range. This strategy has been used by other Barred Owl habitat association studies (Mazur et al. 1997, Dykstra et al. 2012). A sampling unit is hereafter referred to as a "buffer." 


\section{Owl surveys}

We collected detection data at survey sites using both audio lure (callback) and autonomous recording units (ARUs) from 17 January to 9 April 2018. Callback surveys have been successful in detecting Barred Owls (McGarigal and Fraser 1985, Mosher et al. 1990, Kissling et al. 2010). ARUs have proved to be an effective method to detect elusive owls generally (Rognan et al. 2012) and Barred Owls specifically (Shonfield et al. 2018). We started surveys during the courtship period for Barred Owls in our region (Bierregaard, personal communication) to maximize our likelihood of detection, because raptors are known to be more responsive to callbacks during courtship, incubation, and when offspring are young (Bosakowski 1987, Kissling et al. 2010). We surveyed each site using both survey methods during separate sampling occasions. Survey methods did not overlap to ensure independence between callback and ARU detections. As Barred Owls maintain territories interannually (as reviewed in Johnsgard 2002), all detections were assumed to be resident, territorial breeding pairs.

Callbacks consisted of 15-min of Barred Owl vocalizations, altering between 2-phrased hoots and ascending hoots (as described in Mazur and James 2000); calls were spaced approximately $10 \mathrm{~s}$ apart. The broadcast was played at $100 \mathrm{~dB}$ measured $1 \mathrm{~m}$ from the speaker and incorporated 2 silent listening periods ( $1.5 \mathrm{~min})$ and one at the end lasting $3 \mathrm{~min}$. We selected the duration of the audio lure to optimize Barred Owl detection (McGarigal and Fraser 1985), and we selected broadcast sound intensity so that sound would not travel past the minimum spacing between sites ( $750 \mathrm{~m}$; Mosher et al. 1990). Callback surveys began $1 \mathrm{~h}$ past sunset and ended around $0300 \mathrm{EST}$. To minimize travel effort and cost, we structured callback survey order using cluster sampling: Surveys began with a random site and continued in the same cardinal direction from the initial site. We surveyed each site using callbacks on 3 separate occasions. After completing a first round of surveys at all 48 sites, we generated a new random order to follow for the subsequent round. This sampling method optimized survey efficiency while reducing any bias related to time of year. It took $30-37 \mathrm{~d}$ to complete a single round of surveys. We recorded survey variables such as ambient noise and temperature for each site visit (Table 1) to account for changes in detection probability. Although we also recorded variables such as rain and wind, we did not conduct callback surveys if we felt weather conditions considerably impeded surveyor detection probability. Callbacks were conducted by 2 to 5 experienced surveyors.

We conducted passive acoustic surveys with ARUs using SM2+ Song Meters (Wildlife Acoustics Inc., Maynard, Massachusetts, USA) to increase our detection probability. We found little information specific to Barred Owls in the literature to guide our sampling program, so we programmed each ARU to record continuously for $11.5 \mathrm{~h}$ starting at $1900 \mathrm{EST}$. We set ARUs to record at a sampling rate of $8 \mathrm{kHz}$ in the wav format, with the gain settings left to factory default $(+0.0 \mathrm{~dB})$. We tested ARUs prior to deployment to ensure units and their individual paired microphones were functioning properly. We deployed a single ARU at each site to record for 3 consecutive nights and considered 3 nights as a single survey occasion. ARUs were secured to a tree at chest height. If a period of heavy rain occurred during the time of the recording, we recorded an extra day and discarded the rain date to avoid missed detections because of acoustic masking. Deployment order was determined randomly without replacement.

We surveyed all 48 sites with callbacks 3 times. We only surveyed 46 sites with ARUs because logistical constraints prevented us from deploying the ARU at 2 sites. We manually searched recordings for owl calls using SongScope 4.1.5a, a free spectrogram visualization software (Wildlife Acoustics Inc.). Recordings were analyzed by 9 trained interns, using a randomized assignment order. Each of the 3 nightly ARU recordings per site were assessed by different listeners to ensure that the individual's ability did not bias the entire portion of the encounter history. We spent at least $1 \mathrm{~h}$ visually scanning each 11.5-h recording for owl calls. All Barred Owl detections and any unidentified calls were verified by the lead author (M. A. Clement); M. A. Clement and a trained technician also performed random accuracy checks and did not find additional calls. Only recordings with territorial vocalizations were considered to be occupied; this includes variations on the 2-phrased "who-cooksfor-you" and ascending hoots (McGarigal and Fraser 1985, Odom and Mennill 2010). Single hoots were not retained because these are presumed to serve as contact calls rather than territorial display (Odom and Mennill 2010). In addition, single hoots can easily be confused with barking dogs in urban settings, especially if faint or distant. We did not use automated acoustic recognition because existing Barred Owl recognizers have low precision (Shonfield et al. 2018) and human interpreters have higher probability of detection than recognizers for many species (Venier et al. 2017).

\section{Habitat characteristics}

We selected habitat metrics likely to influence Barred Owl occupancy based on review of the literature (Table 1). We used ArcGIS 10.3.1 (Environmental Systems Research Institute Inc., Redlands, California, USA) and a variety of publicly available spatial data sets to estimate these metrics for each 400-m buffer. We used data from the 2018 National Wetland Inventory (U.S. Department of the Interior, Fish and Wildlife Service 2018) to calculate wetland area, excluding open water and large lakes such as Lake Hartwell. We calculated stream density by extracting total stream length within each buffer using South Carolina's Department of Natural Resources (SC DNR) hydrography layer (http://www.dnr.sc.gov/GIS/gisdownload.html). To build finescale landcover classes, we obtained $0.3-\mathrm{m}$ resolution aerial imagery from 3 counties in our study region: Anderson (2017), Oconee (2015), and Pickens county (2016). We used ArcGIS's Support Vector Machine (SVM) classifier tool to do a supervised classification on the aerial imagery. SVM classification can handle small training samples and is more accurate than maximized likelihood classification in heterogenous urban landscapes (van der Linden et al. 2007, Mountrakis et al. 2011). We extracted 3 habitat variables, i.e., deciduous forest, coniferous forest, and impervious surface, and classified all other features as "other." We resampled the output of the classification to 3-m resolution using majority resampling to smooth out graininess. We created and evaluated 400 accuracy points on this classification and found our classification to be $90 \%$ accurate (kappa index of agreement). To obtain results comparable beyond our study region, we converted all land cover variables to densities by dividing length or total area values by the area of buffers $\left(\sim 0.5 \mathrm{~km}^{2}\right)$. 
We estimated average tree height within buffers using airborne light detection and ranging (LiDAR) data from the 2011 SC DNR Tricounty data set (National Oceanic and Atmospheric Administration Digital Coast 2011). This data set had an average point density of 2.5 points $/ \mathrm{m}^{2}$ and was collected between 8 and 13 March 2011. We used the LAStools software suite (Isenburg 2007) to process LiDAR point cloud data. We classified ground points using lasground_new, computed elevation using lasheight, and extracted tree canopy points using lasclassify with vegetation height threshold $>2 \mathrm{~m}$. We created 2 separate raster data sets with a spatial resolution of $2 \mathrm{~m}^{2}$ for tree elevation and ground elevation and then subtracted tree elevation from ground elevation to obtain tree height. To account for rapid land-use change that occurred in our region since 2011, we used a combined layer of deciduous and coniferous forest extracted from our SVM classification to remove forested areas that were cleared after the 2011 imagery was generated.

\section{Occupancy analysis}

To investigate habitat associations of Barred Owls along a development gradient, we used occupancy modeling (Mackenzie et al. 2002) to account for imperfect detection and repeated observations. Using R version 3.5.0 (R Core Team 2018) within R Studio (RStudio Team 2016), we used single-season occupancy models with the package "unmarked" (Fiske and Chandler 2011). We assumed that a single-season approach would be appropriate for Barred Owls because they are known to maintain established territories year-round (as reviewed in Johnsgard 2002). For each site, we kept the 3 callback observations as unique sampling occasions but compiled the 3-night recordings of ARUs into a single sampling occasion. Sites that had missing ARU recordings $(n=2)$ were kept in our data set as "NA," because occupancy modeling allows for missing sampling occasions.

We screened for collinearity of site variables using both Pearson's correlation matrices at threshold $|r|=0.70$ and the variance inflation factor at the vif $=0.30$ threshold. Because of the fragmented and variable nature of our region, we did not find significant collinearity between any variables $(\max |r|<0.51$; Appendix 1). We scaled and centered all continuous variables to mean $=0$ and variance $=1$ prior to analysis.

We used a two-step ad hoc approach (MacKenzie et al. 2006) to select which detection covariates to include in the occupancy models. We first estimated the effect of detection parameters by holding occupancy constant and then incorporated significant detection covariates in the full occupancy models. As a preliminary step, we ranked univariate models of callback detection covariates separately from ARU data (Table 2) because callback covariates were time specific and ARU data spanned 3 nights. Date was the only parameter with substantial support in the preliminary assessment of callback-detection covariates (AICcWt $=0.86$, evidence ratio 19.3 between models "date" and second-ranked "noise"), so we incorporated date along with a survey "method" covariate that represented either callback or ARU as categorical variables for analysis with the full data set (Table 3). In a second step, we incorporated the top-ranked detection models for combined callbacks and ARU data in the occupancy models of the full data set.

To examine Barred Owl habitat associations along a development gradient, we used a multiple working hypotheses framework
(Burnham and Anderson 2002) to compare eight models (Table 4). We suspected riparian corridors would be more important to owls as urbanization increased, so we included a context-specific "riparian" model that featured an interaction between impervious surface cover and stream density. We included a "conventional" model that combined habitat characteristics commonly associated with Barred Owl habitat in the literature: mature trees and wetlands (Bosakowski and Smith 1997, Johnsgard 2002). To assess association with forest type and cover, we evaluated a "forest" model that included area of deciduous trees and coniferous trees as two separate covariates. We hypothesized Barred Owl occupancy would be greater in deciduous forest than in coniferous forest because they are more likely to nest in deciduous trees (as reviewed in Livezey 2007). We added an "aquatic" model to investigate whether occupancy probability was primarily driven by wetlands and streams. We suspected tree height and degree of urbanization would strongly influence occupancy probability, so we included "mature trees" (tree height) and "urban" (impervious surface) as univariate models.

Table 2. Detection variables collected during callback surveys for Barred Owls (Strix varia). All variables were collected on-site at the time of survey except for ILLUMI and PASTSSET, which were calculated postsurvey using http://www.timeanddate.com.

\begin{tabular}{|c|c|c|}
\hline Variables & Description & Collection Method \\
\hline TEMP & $\begin{array}{l}\text { Temperature may influence } \\
\text { owl activity. }\end{array}$ & Celsius (range: $-4^{\circ}$ to $19^{\circ}$ ) \\
\hline PRECIP & $\begin{array}{l}\text { Precipitation may reduce } \\
\text { owl activity and surveyor } \\
\text { detection. }\end{array}$ & Presence or absence \\
\hline NOISE & $\begin{array}{l}\text { Ambient noise may reduce } \\
\text { acoustic detection. }\end{array}$ & Estimate, low or high \\
\hline CLOUD & $\begin{array}{l}\text { Cloud cover may reduce } \\
\text { visual detection. }\end{array}$ & Estimate, percent cover \\
\hline ILLUMI & $\begin{array}{l}\text { Moonlight illumination may } \\
\text { increase owl activity and } \\
\text { surveyor detection. }\end{array}$ & $\begin{array}{l}\text { (Lunar altitude }>0) \times \% \\
\text { crescent; } \\
0=\text { no moon }\end{array}$ \\
\hline TIME & $\begin{array}{l}\text { Time of survey may } \\
\text { influence activity of owls } \\
\text { and surveyor detection. }\end{array}$ & Time at start of survey \\
\hline DATE & $\begin{array}{l}\text { Day of year; seasonality } \\
\text { may influence activity and } \\
\text { surveyor detection. }\end{array}$ & Julian calendar \\
\hline WIND & $\begin{array}{l}\text { Wind may decrease both } \\
\text { visual and acoustic } \\
\text { detection. }\end{array}$ & $\begin{array}{l}\text { Beaufort scale, high }(\geq 2) \text { or } \\
\text { low }(<2)\end{array}$ \\
\hline EFFORT & $\begin{array}{l}\text { Number of surveyors may } \\
\text { influence surveyor } \\
\text { detection. }\end{array}$ & $\begin{array}{l}\text { High: } 3-4 \text { surveyors } \\
\text { Low: } 2 \text { surveyors }\end{array}$ \\
\hline PASTSSET & $\begin{array}{l}\text { Time past sunset may } \\
\text { influence owl activity. }\end{array}$ & Decimal hours \\
\hline
\end{tabular}

Prior to running our analyses, we examined if our global model adequately fit our data using parametric bootstrapping (Burnham and Anderson 2002, MacKenzie and Bailey 2004). This step ensures that candidate models adequately describe the observed data (MacKenzie et al. 2006). We used the $R$ package "AICcmodavg" (Mazerolle 2017) to compute the goodness-of-fit test for single-season occupancy models based on Pearson's chisquare on 1000 iterations. We assumed adequate model fit and did not add an overdispersion parameter $(\hat{c})$ because our $p$ value 
Table 3. AICc model-ranked results for all models evaluating detection probability covariates associated with Barred Owl (Strix varia) surveys across a development gradient in the Piedmont of South Carolina. The interactive model (DATE $\times$ METHOD) was the best model and was incorporated in the occupancy models. AICc, AICc score; AICcWt, Akaike weight; Cumm.Wt, cummulative Akaike weight from maximum to minimum; $\triangle \mathrm{AICc}$, difference between the model's AICc and the AICc of the best-fitting model in the model set; $K$, number of parameters; LogLik, log likelihood.

\begin{tabular}{|c|c|c|c|c|c|c|c|}
\hline Hypothesis & Model & $K$ & $\mathrm{AICc}$ & $\triangle \mathrm{AICc}$ & $\mathrm{AICcWt}$ & LogLik & Cumm.Wt \\
\hline Interactive & DATE $\times$ METHOD & 5 & 208.24 & 0.00 & 0.50 & -98.40 & 0.50 \\
\hline Date & DATE & 3 & 209.86 & 1.62 & 0.22 & -101.66 & 0.73 \\
\hline Null & --- & 2 & 211.28 & 3.04 & 0.11 & -101.17 & 0.84 \\
\hline Additive & DATE + METHOD & 4 & 211.33 & 3.09 & 0.11 & -103.53 & 0.95 \\
\hline Method & METHOD & 3 & 212.76 & 4.52 & 0.05 & -103.11 & 1.00 \\
\hline
\end{tabular}

was $>0.05(p=0.088)$ and the $\hat{c}$ was close to 1 . We used an information theoretic approach and the Akaike information criterion adjusted for small sample size (AICc) to compare relative support among our competing models using log likelihoods (Burnham and Anderson 2002). We interpreted models with substantial empirical support $(\triangle \mathrm{AICc}<2$; Burnham and Anderson 2002), and we considered parameters to be informative if the $85 \%$ confidence intervals did not include 0 (Arnold 2010).

\section{RESULTS}

We conducted 144 callback surveys ( 3 visits $\times 48$ sites) and scanned 138 nightly 11.5 -h audio recordings ( 3 recordings $\times 46$ sites). Using the combined ARU and callback methods, we detected Barred Owls at 27 of the 48 surveyed sites (56\%). Of these 27 occupied sites, $13(48 \%)$ were sites with an HM-T value above 0.40 (Fig. 2). For comparative purposes, the average HM$\mathrm{T}$ is 0.38 for the United States and 0.20 for our study region. We detected Barred Owls at 22 sites using callback surveys and at 14 sites using ARUs. Only 11 sites had detections from both callback and ARUs.

The detection-only model with the most support included an interaction between method, i.e., ARU or survey, and date (Table 3 ); thus the interaction of these covariates was included in the occupancy models. Average detection probability associated with ARUs throughout the sampling season was 0.49 (standard error $[\mathrm{SE}] \pm 0.10$ ), and the average detection probability using callback surveys was 0.39 ( $\mathrm{SE} \pm 0.06)$. Callbacks became an increasingly effective survey method as the breeding season progressed, and ARUs were more effective earlier in the season (Fig. 3).

The conventional model and the tree height model were the only occupancy models among our candidate set that had substantial support (AICc cumulative weight $=0.70$ ). In the conventional model, both tree height and wetland area had positive effects on the probability of Barred Owl occupancy (Fig. 4). Tree height was a more informative parameter $(\beta=0.70, \mathrm{SE} \pm 0.40,85 \%$ confidence interval $[\mathrm{CI}]=0.12,1.28)$ for Barred Owl occupancy probability than wetland area $(\beta=1.31, \mathrm{SE} \pm 1.14,85 \% \mathrm{CI}[-0.33$, $2.95]$ ), as the confidence intervals of wetland area overlapped 0 . However, the addition of the wetland parameter to tree height in the "conventional" model improved model fit (Table 4). No other model, including the "urban" and the "forest" models, were substantially supported by our data.
Fig. 3. Detection probability of Barred Owls (Strix varia) varies with the interaction of DATE and METHOD, i.e., callback or autonomous recording unit (ARU). Survey methods began in early January and ended in early April 2018. ARUs were more effective earlier in the breeding season, and callbacks became more effective as the breeding season progressed. ARU surveys are a compilation of 3 consecutive nights of 11.5-h recordings; callback surveys are 15-min observation periods while using conspecific broadcast. Shaded areas are $85 \%$ confidence intervals.

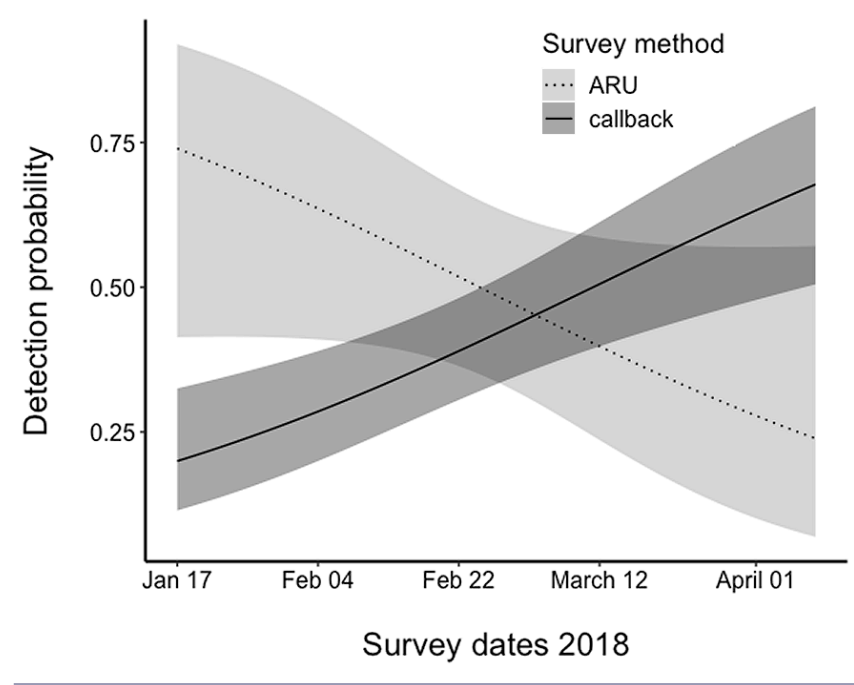

\section{DISCUSSION}

Although Barred Owls are almost exclusively described as inhabiting contiguous mature forest, our research demonstrates that Barred Owls can occupy developed areas provided certain habitat requirements are met. A number of past studies have implied that Barred Owls avoid development (Bosakowski and Smith 1997, Grossman et al. 2008), yet Barred Owl occupancy did not decrease with impervious surface in our study region. Nearly half of the sites with owl detections were considerably developed (48\% had HM-T > 0.40). Across the development gradient, we found average tree height was the best estimator of Barred Owl occupancy probability, which suggests that habitat structure is critical to Barred Owl presence in developed 
Table 4. AICc model-ranked results for occupancy models evaluating various site covariates associated with Barred Owl (Strix varia) habitat use across a development gradient in the Piedmont of South Carolina. We considered models with $\triangle \mathrm{AICc}<2$ to have substantial support (Burnham and Anderson 2002). The interaction of detection covariates DATE and METHOD was included in all models. AICc, AICc score; AICcWt, Akaike weight; Cumm.Wt, cummulative Akaike weight from maximum to minimum; $\triangle \mathrm{AICc}$, difference between the model's AICc and the AICc of the best-fitting model in the model set; $K$, number of parameters; LogLik, log likelihood.

\begin{tabular}{|c|c|c|c|c|c|c|c|}
\hline Hypothesis & Model & $K$ & $\mathrm{AICc}$ & $\triangle \mathrm{AICc}$ & $\mathrm{AICcWt}$ & LogLik & Cumm.Wt \\
\hline Conventional & WETLAND + TREE HEIGHT & 7 & 205.51 & 0.00 & 0.46 & -94.36 & 0.46 \\
\hline Mature trees & TREE HEIGHT & 6 & 206.77 & 1.26 & 0.24 & -96.36 & 0.70 \\
\hline Null & 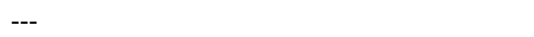 & 5 & 208.24 & 2.73 & 0.12 & -98.40 & 0.82 \\
\hline Aquatic & STREAM + WETLAND & 7 & 208.93 & 3.42 & 0.08 & -96.07 & 0.90 \\
\hline Urban & IMPERV & 6 & 209.26 & 3.75 & 0.07 & -97.60 & 0.97 \\
\hline Forest & DECID + CONIF & 7 & 212.47 & 6.96 & 0.01 & -97.84 & 0.99 \\
\hline Riparian & IMPERV × STREAM & 8 & 213.20 & 7.69 & 0.01 & -96.76 & 1.00 \\
\hline Global & $\begin{array}{l}\text { WETLAND + TREE HEIGHT + IMPERV } \\
+ \text { STREAM + DECID + CONIF }\end{array}$ & 11 & 216.05 & 10.53 & 0.00 & -93.36 & 1.00 \\
\hline
\end{tabular}

Fig. 4. Barred Owl (Strix varia) probability of occupancy increases with tree height and wetland cover in the Piedmont of South Carolina. Wetland cover is categorized for the purpose of plotting as high (values above upper quantile, $>1.91 \%$ ) and low (values below lower quantile, $<0.55 \%$ ). In the analysis, wetland cover was a continuous variable. Occupancy was predicted from the best-supported conventional model. Shaded areas are $85 \%$ confidence intervals.

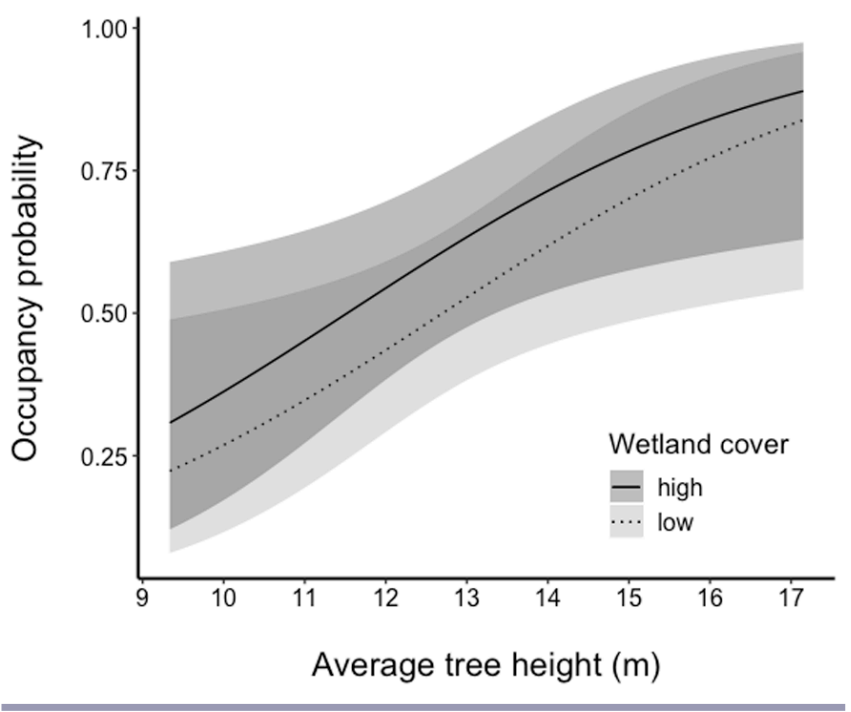

landscapes. Large mature trees are more likely to provide suitable nest cavities, and nest availability is frequently described as a limiting factor for Barred Owls (as reviewed in Johnsgard 2002). Because neither deciduous nor coniferous forest area was a parameter featured in the top-ranking models, tree maturity appears to be a better predictor of Barred Owl occupancy than total forest coverage in our study region. This indicates that individual or small patches of large trees can meet the habitat requirements of Barred Owls.

We found a weak positive effect of wetland density on Barred Owl occupancy probability. In a literature review of 144 habitat studies, Livezey (2007) found mixed results concerning the association of Barred Owls with aquatic features; yet in comparison to other raptors, Barred Owls frequently nest near water (Livezey 2007, Wiens et al. 2014). Large trees at the periphery of wetlands could provide Barred Owls additional nesting opportunities because moist soils can accelerate tree growth and reduce frequency of fire. Wetlands may also provide abundant foraging opportunities, particularly during the anuran breeding season. Barred owls will readily take aquatic prey and have been known to hunt frogs, fish, and aquatic invertebrates (Hamer et al. 2001, Livezey 2007, Cauble 2008). Barred Owl association with wetlands may depend on landscape context because urban wetlands are often impaired and as a result contain lower species richness and abundance of potential prey (Findlay and Houlahan 1997, Knutson et al. 1999). This aspect should be further explored with additional movement studies in a variety of urban landscapes.

Average detection probability of Barred Owls using callbacks and ARU survey methods were similar to studies that reported this parameter (Bailey et al. 2009, Kissling et al. 2010, Shonfield and Bayne 2017). ARUs had higher average detection probability than callbacks across the survey season; however, ARU samples as defined in this study compiled recordings from three consecutive nights at each site. When modeling detection probability, we observed an interaction between the effect of date and survey method. As the season progressed, detection probability increased for callbacks, whereas it decreased for ARUs (Fig. 3). As ARUs passively record without use of a lure, detection probability should represent the natural vocalization patterns for this species. Owl vocalizations peak just prior to egg laying (as reviewed in Johnsgard 2002), suggesting that more frequent ARU detections should occur earlier in the breeding season. Our ARU surveys were completed prior to major leaf out; therefore, sound attenuation from leaves was unlikely to have an effect on detection probability. In contrast, callbacks became increasingly effective as the breeding season progressed. Kissling et al. (2010) found a similar positive effect of date on detection probability for callbacks during the breeding season. Although natural calling behavior decreases as the season progresses, territorial responses to conspecific calls may increase when breeding pairs are defending active nests or fledglings.

Although we designed our study to minimize sources of bias, there are limitations that may have influenced our findings. As survey sites were obtained from random spatial selection rather than 
from known cores of owl territories, such as a nest site, we cannot assume that owls consistently remained within the $400 \mathrm{~m}$ radius buffer during the survey window. Hence, occupancy results at this scale are best described as probability of "use" rather than occupancy, a recommendation by MacKenzie et al. (2006) that several comparable studies have employed (Kissling et al. 2010, Shonfield and Bayne 2017). Future research that evaluates finescale owl movements using GPS telemetry will provide a more robust evaluation of the influence of the predictors considered in our coarse-scale occupancy analysis.

Although our study demonstrates that Barred Owls occupy certain areas in developed landscapes, we cannot infer that these areas are advantageous habitats or ecological traps (Schlaepfer et al. 2002). Mason (2004) suggests Barred Owls in downtown Charlotte, North Carolina, USA, produce more chicks compared with Barred Owls in nearby forested habitats. Differential productivity may result, in part, because suburban environments can produce higher biomass of potential prey for raptors than native habitats (Chace and Walsh 2006). As dietary generalists, Barred Owls feed on abundant rodent and avian prey in suburban environments (Cauble 2008, Hindmarch and Elliott 2015). In addition, the open understory of suburban landscapes can provide ideal open foraging habitat, free of flight obstruction, much like the open understory of a mature forest (Harrold 2003; Fig. 1). Despite these advantages, developed settings pose many hazards for Barred Owls. Apex predators are exposed to increased bioaccumulation of toxic substances and pesticides from human activity (Sheffield 1997, Newsome et al. 2010, Henny et al. 2011). In British Columbia, a study found that rat consumption exposed Barred Owls to anticoagulant rodenticides (Hindmarch and Elliott 2015), sometimes at levels causing direct mortality. Barred Owls, like many other birds of prey, are also frequent victims of vehicle collisions. Recent data from the Carolina Raptor Center (Charlotte, North Carolina, USA) suggests that Barred Owls are some of the most frequent birds of prey to be brought in from vehicle strikes (Gagné et al. 2015). Demographic studies are needed to determine if the benefits of developed areas outweigh the costs for Barred Owls.

Our research highlights the ability of Barred Owls to occupy areas that have been developed for residential or commercial use, particularly in southeastern wooded suburbs (Bierregaard 2018). This finding contrasts historical descriptions of Barred Owl habitat associations in widely cited literature reviews (Johnsgard 2002, Livezey 2007). The plasticity of Barred Owls may have contributed to their rapid invasion into the range of Spotted Owls (Strix occidentalis) in the western United States, via corridors of reforested regions accompanying settlement across the Great Plains (Livezey 2009). Results of our study build on other research investigating how certain raptor species can respond positively to urban landscapes (Rullman and Marzluff 2014, Millsap 2018, White et al. 2018). In a meta-analysis of biodiversity variation of cities across the world, Beninde et al. (2015) found that urban bird richness in cities was best predicted by tree structure and tree cover. Our study indicates that mature urban canopy may be critical to sustain Barred Owls in urban areas. As a tertiary and secondary consumer, Barred Owls may serve the function of an umbrella species; the management and protection of Barred Owls could indirectly protect other wildlife sensitive to anthropogenic change (Lambeck 1997, Rubino 2001, Hess and King 2002).
Examining Barred Owl occupancy of urban landscapes may give experts insight on the best strategies to plan for development with higher urban habitat quality supporting greater biota diversity. Notably, Barred Owls are a highly charismatic and visible species across our study region. Expanding public exposure and interaction with this species could prove to be an important basis for a conservation education strategy focused on appreciation of urban biodiversity (Nilon 2011).

Responses to this article can be read online at: http://www.ace-eco.org/issues/responses.php/1427

\begin{abstract}
Acknowledgments:
This project was funded and supported by the Margaret H. LloydSmartState Endowment for Urban Ecology and Restoration and the Clemson Creative Inquiry Program. We are indebted to the student technicians, A. Michaeli, A. Carter, and interns A. Arthur, K. Brown, E. Jordan, J. Kiel, I. Pacheco, S. Parham, and K. Peters for their assistance surveying and analyzing recordings. In particular, we thank Paul Leonard and Claire Stuyck for initiating this project, Rob Bierregaard and Brian Ritter for their guidance, and graduate committee members Patrick Jodice and Catherine Jachowski for lending their expertise to the project.
\end{abstract}

\section{LITERATURE CITED}

Arnold, C. L., Jr., and C. J. Gibbons. 1996. Impervious surface coverage: the emergence of a key environmental indicator. Journal of American Planning Association 62(2):243-258. https://doi. org/10.1080/01944369608975688

Arnold, T. W. 2010. Uninformative parameters and model selection using Akaike's information criterion. Journal of Wildlife Management 74(6):1175-1178. https://doi.org/10.2193/2009-367

Bailey, L. L., J. A. Reid, E. D. Forsman, and J. D. Nichols. 2009. Modeling co-occurrence of Northern Spotted and Barred Owls: accounting for detection probability differences. Biological Conservation 142:2983-2989. https://doi.org/10.1016/j.biocon.2009.07.028

Beninde, J., M. Veith, and A. Hochkirch. 2015. Biodiversity in cities needs space: a meta-analysis of factors determining intraurban biodiversity variation. Ecology Letters 18(6):581-592. https://doi.org/10.1111/ele.12427

Bierregaard, R. O. 2018. Barred Owls: a nocturnal generalist thrives in wooded, suburban habitats. Pages 138-151 in C. W. Boal and C. R. Dykstra, editors. Urban raptors: ecology ad conservation of birds of prey in cities. Island, Washington, D.C., USA. https:// doi.org/10.5822/978-1-61091-841-1_10

Bosakowski, T. 1987. Census of Barred Owls and Spotted Owls. Pages 307-308 in Biology and Conservation of Northern Forest Owls Symposium (Winnipeg, Manitoba, Canada, 1987). U.S. Forest Service, Rocky Mountain Forest and Range Experiment Station, Fort Collins, CO, USA.

Bosakowski, T., and D. G. Smith. 1997. Distribution and species richness of a forest raptor community in relation to urbanization. Journal of Raptor Research 31(1):26-33. 
Avian Conservation and Ecology 14(2): 12

Brown, D. G., K. M. Johnson, T. R. Loveland, and D. M. Theobald. 2005. Rural land-use trends in the conterminous United States, 1950-2000. Ecological Applications 15 (6):1851-1863. https://doi.org/10.1890/03-5220

Burnham, K. P., and D. R. Anderson. 2002. Model selection and multimodel inference: a practical information-theoretic approach. Second edition. Springer-Verlag, New York, New York, USA.

Cauble, L. C. 2008. The diets of rural and suburban Barred Owls (Strix varia) in Mecklenburg County, North Carolina. Thesis. University of North Carolina, Charlotte, North Carolina, USA.

Chace, J. F., and J. J. Walsh. 2006. Urban effects on native avifauna: a review. Landscape and Urban Planning 74:46-69. https://doi.org/10.1016/j.landurbplan.2004.08.007

Dykstra, C. R., M. M. Simon, F. B. Daniel, and J. L. Hays. 2012. Habitats of suburban Barred Owls (Strix varia) and RedShouldered Hawks (Buteo lineatus) in southwestern Ohio. Journal of Raptor Research 46(2):190-200. https://doi.org/10.3356/ JRR-11-05.1

Estes, W. A., and R. W. Mannan. 2003. Feeding behavior of Cooper's Hawks at urban and rural nests in southeastern Arizona. Condor 105:107-116. https://doi.org/10.1650/0010-5422(2003) 105[107:FBOCHA]2.0.CO;2

Findlay, C. S., and J. Houlahan. 1997. Anthropogenic correlates of species richness in southeastern Ontario wetlands. Conservation Biology 11(4):1000-1009. https://doi.org/10.1046/ j.1523-1739.1997.96144.x

Fiske, I. J., and R. B. Chandler. 2011. unmarked: an R package for fitting hierarchical models of wildlife occurrence and abundance. Journal of Statistical Software 43(10):1-23. https:// doi.org/10.18637/jss.v043.i10

Gagné, S. A., J. L. Bates, and R. O. Bierregaard. 2015. The effects of road and landscape characteristics on the likelihood of a Barred Owl (Strix varia)-vehicle collision. Urban Ecosystems 18 (3):1007-1020. https://doi.org/10.1007/s11252-015-0465-5

Grossman, S. R., S. J. Hannon, and A. Sánchez-Azofeifa. 2008. Responses of Great Horned Owls (Bubo virginianus), Barred Owls (Strix varia), and Northern Saw-whet Owls (Aegolius acadicus) to forest cover and configuration in an agricultural landscape in Alberta, Canada. Canadian Journal of Zoology 86:1165-1172. https://doi.org/10.1139/Z08-095

Hamer, T. E., D. L. Hays, C. M. Senger, and E. D. Forsman. 2001. Diets of Northern Barred Owls and Northern Spotted Owls in an area of sympatry. Journal of Raptor Research 35(3):221-227.

Haney, C. J. 1997. Spatial incidence of Barred Owl (Strix varia) reproduction in old-growth forest of the Appalacian Plateau. Journal of Raptor Research 31(3):241-252.

Harrold, E. S. 2003. Barred Owl (Strix varia) nesting ecology in the southern Piedmont of North Carolina. Thesis. University of North Carolina, Charlotte, North Carolina, USA.

Henny, C. J., R. A. Grove, J. L. Kaiser, B. L. Johnson, C. V. Furl, and R. J. Letcher. 2011. Wastewater dilution index partially explains observed polybrominated diphenyl ether flame retardant concentrations in Osprey eggs from Columbia River Basin, 2008-
2009. Ecotoxicology 20(4):682-697. https://doi.org/10.1007/ s10646-011-0608-2

Hepinstall, J. A., M. Alberti, and J. M. Marzluff. 2008. Predicting land cover change and avian community responses in rapidly urbanizing environments. Landscape Ecology 23(10):1257-1276. https://doi.org/10.1007/s10980-008-9296-6

Hess, G. R., and T. J. King. 2002. Planning open spaces for wildlife: I. Selecting focal species using a Delphi survey approach. Landscape and Urban Planning 58(1):25-40. https://doi. org/10.1016/S0169-2046(01)00230-4

Hindmarch, S., and J. E. Elliott. 2015. When owls go to town: the diet of urban Barred Owls. Journal of Raptor Research 49 (1):66-74. https://doi.org/10.3356/jrr-14-00012.1

Homer, C., J. Dewitz, L. Yang, S. Jin, P. Danielson, G. Xian, J. Coulston, N. Herold, J. Wickham, and K. Megown. 2015. Completion of the 2011 National Land Cover Database for the conterminous United States - representing a decade of land cover change information. Photogrammetric Engineering and Remote Sensing 81(5):345-354.

Isenburg, M. 2007. LAStools: efficient LiDAR processing software (version 171030, academic). rapidlasso $\mathrm{GmbH}$, Gilching, Germany. [online] URL: http://rapidlasso.com/LAStools

Johnsgard, P. A. 2002. North American owls : biology and natural history. Second edition. Smithsonian Institution, Washington, D. C., USA.

Kincaid, T. M., and A. R. Olsen. 2016. spsurvey: spatial survey design and analysis. $\mathrm{R}$ package version 3.3. R Foundation for Statistical Computing, Vienna, Austria.

Kissling, M. L., S. B. Lewis, and G. Pendleton. 2010. Factors influencing the detectability of forest owls in southeastern Alaska. Condor 112(3):539-548. https://doi.org/10.1525/cond.2010.090217

Kluza, D. A., C. R. Griffin, and R. M. Degraaf. 2000. Housing developments in rural New England: effects on forest birds. Animal Conservation 3(1):15-26. https://doi.org/10.1111/j.1469-1795.2000. tb00083.X

Knutson, M. G., J. R. Sauer, D. A. Olsen, M. J. Mossman, L. M. Hemesath, and M. J. Lannoo. 1999. Effects of landscape composition and wetland fragmentation on frog and toad abundance and species richness in Iowa and Wisconsin, U.S.A. Conservation Biology 13(6):1437-1446. https://doi.org/10.1046/ j.1523-1739.1999.98445.x

Lambeck, R. J. 1997. Focal species: a multi-species umbrella for nature conservation. Conservation Biology 11(4):849-856. https:// doi.org/10.1046/j.1523-1739.1997.96319.x

Livezey, K. B. 2007. Barred Owl habitat and prey: a review and synthesis of the literature. Journal of Raptor Research 41 (3):177-201. https://doi.org/10.3356/0892-1016(2007)41[177:BOHAPA] 2.0.CO;2

Livezey, K. B. 2009. Range expansion of Barred Owls, part II: facilitating ecological changes. American Midland Naturalist 161 (2):323-349. https://doi.org/10.1674/0003-0031-161.2.323

MacKenzie, D. I., and L. L. Bailey. 2004. Assessing the fit of siteoccupancy models. Journal of Agricultural, Biological, and 
Avian Conservation and Ecology 14(2): 12

Environmental Statistics 9(3):300-318. https://doi. org/10.1198/108571104X3361

Mackenzie, D. I., J. D. Nichols, G. B. Lachman, S. Droege, J. A. Royel, and C. A. Langtimm. 2002. Estimating site occupancy rates when detection probabilities are less than one. Ecology 83 (8):2248-2255. https://doi.org/10.1890/0012-9658(2002)083[2248: ESORWD]2.0.CO;2

MacKenzie, D. I., J. D. Nichols, and N. G. Yoccoz. 2006. Occupancy estimation and modeling: inferring patterns and dynamics of species occurrence. Academic, Burlington, Massachusetts, USA.

Mason, J. S. 2004. The reproductive sucess, survival, and natal dispersal of Barred Owls (Strix Varia) in rural versus urban habitats in and around Charlotte, North Carolina. Dissertation. University of North Carolina, Charlotte, North Carolina, USA.

Mazerolle, M. J. 2017. AICcmodavg: model selection and multimodel inference based on $(Q) A I C(c)$. $\mathrm{R}$ package version 2.1-1. R Foundation for Statistical Computing, Vienna, Austria.

Mazur, K. M., and P. C. James. 2000. Barred Owl (Strix varia). In A.F. Poole and F. B. Gill, editors. The birds of North America. Cornell Lab of Ornithology, Ithaca, New York, New York, USA. https://doi.org/10.2173/bna.508

Mazur, K. M., P. C. James, M. J. Fitzsimmons, G. Langen, and R. H. M. Espie. 1997. Habitat associations of the Barred Owl in the boreal forest of Saskatchewan, Canada. Journal of Raptor Research 31(3):253-259.

McGarigal, K., and J. D. Fraser. 1985. Barred Owl responses to recorded vocalizations. Condor 87(4):552-553. https://doi. org/10.2307/1367961

McKinney, M. L. 2002. Urbanization, biodiversity, and conservation. BioScience 52(10):883-890. https://doi.org/10.1641/0006-3568 (2002)052[0883:UBAC]2.0.CO;2

McLaren, M. A., I. D. Thompson, and J. A. Baker. 1998. Selection of vertebrate wildlife indicators for monitoring sustainable forest management in Ontario. Forestry Chronicle 74(2):241-248. https://doi.org/10.5558/tfc74241-2

Medley, K. E., M. J. McDonnell, and S. T. A. Pickett. 1995. Forestlandscape structure along an urban-to-rural gradient. Professional Geographer 47(2):159-168.

Millsap, B. A. 2018. Demography and metapopulation dynamics of an urban Cooper's Hawk subpopulation. Condor 120(1):63-80. https://doi.org/10.1650/CONDOR-17-124.1

Mosher, J. A., M. R. Fuller, and M. Kopeny. 1990. Surveying woodland raptors by broadcast of conspecific vocalizations. Journal of Field Ornithology 61(4):453-461.

Mountrakis, G., J. Im, and C. Ogole. 2011. Support vector machines in remote sensing: a review. ISPRS Journal of Photogrammetry and Remote Sensing 66:247-259. https://doi. org/10.1016/j.isprsjprs.2010.11.001

National Oceanic and Atmospheric Administration (NOAA) Digital Coast. 2011. Data Access Viewer: 2011 South Carolina DNR Lidar: Tricounty (Anderson, Oconee, Pickens). NOAA Office for Coastal Management, Charleston, South Carolina,
USA. [online] URL: https://coast.noaa.gov/htdata/lidar1_z/ geoid12b/data/4982

Newsome, S. D., J.-S. Park, B. W. Henry, A. Holden, M. L. Fogel, J. Linthicum, V. Chu, and K. Hooper. 2010. Polybrominated diphenyl ether (PBDE) levels in Peregrine Falcon (Falco peregrinus) eggs from California correlate with diet and human population density. Environmental Science and Technology 44 (13):5248-5255. https://doi.org/10.1021/es100658e

Nicholls, T. H., and D. W. Warner. 1972. Barred Owl habitat use as determined by radiotelemetry. Journal of Wildlife Management 36(2):213-224

Nilon, C. H. 2011. Urban biodiversity and the importance of management and conservation. Landscape and Ecological Engineering 7(1):45-52. https://doi.org/10.1007/s11355-010-0146-8

Odom, K. J., and D. J. Mennill. 2010. A quantitative description of the vocalizations and vocal activity of the Barred Owl. Condor 112(3):549-560. https://doi.org/10.1525/cond.2010.090163

R Core Team. 2018. R: a language and environment for statistical computing. R Foundation for Statistical Computing, Vienna, Austria.

Rognan, C. B., J. M. Szewczack, and M. L. Morrison. 2012. Autonomous recording of Great Gray Owls in the Sierra Nevada. Northwestern Naturalist 93(2):138-144. https://doi.org/10.1898/ nwn11-02.1

RStudio Team. 2016. RStudio: integrated development for $R$. RStudio Inc., Boston, Massachusetts, USA.

Rubino, M. J. 2001. Identifying Barred Owl habitat in the North Carolina piedmont: using GIS in focal species conservation planning. Thesis. North Carolina State University, Charlotte, North Carolina, USA.

Rullman, S., and J. M. Marzluff. 2014. Raptor presence along an urban-wildland gradient: influences of prey abundance and land cover. Journal of Raptor Research 48(3):257-272. https://doi. org/10.3356/JRR-13-32.1

Schlaepfer, M. A., M. C. Runge, and P. W. Sherman. 2002. Ecological and evolutionary traps. Trends in Ecology and Evolution 17(10):474-480. https://doi.org/10.1016/S0169-5347 (02)02580-6

Sheffield, S. R. 1997. Owls as biomonitors of environmental contamination. Pages 383-398 in Biology and conservation of owls of the Northern Hemisphere: Second International Owl Symposium (Winnipeg, Manitoba, Canada, 1997). U.S. Forest Service, North Central Forest Experiment Station, St. Paul, Minnesota, USA.

Shonfield, J., and E. M. Bayne. 2017. The effect of industrial noise on owl occupancy in the boreal forest at multiple spatial scales. Avian Conservation and Ecology 12(2):13. https://doi.org/10.5751/ ACE-01042-120213

Shonfield, J., S. Heemskerk, and E. M. Bayne. 2018. Utility of automated species recognition for acoustic monitoring of owls. Journal of Raptor Research 52(1):42-55. https://doi.org/10.3356/ JRR-17-52.1

Stevens, D. L., Jr., and A. R. Olsen. 2004. Spatially balanced sampling of natural resources. Journal of the American Statistical Association 99:262-278. https://doi.org/10.1198/016214504000000250 
Theobald, D. M. 2013. A general model to quantify ecological integrity for landscape assessments and US application. Landscape Ecology 28(10):1859-1874. https://doi.org/10.1007/ s10980-013-9941-6

U.S. Department of Agriculture (USDA). 2004. Appendix II: management indicator species and habitats. Pages II-1-II-2 in 2004 Land and resource management plan: Chequamegon-Nicolet National Forests. U.S. Forest Service, Eastern Region, Milwaukee, Wisconsin, USA.

U.S. Department of the Interior, Fish and Wildlife Service. 2018. U.S. Fish and Wildlife Service National Wetlands Inventory Version 2: surface waters and wetlands inventory vector digital data classification of wetlands and deepwater habitats of the United States. U.S. Department of the Interior, Fish and Wildlife Service, Washington, D.C., USA. [online] URL: https://www.fws.gov/ wetlands/Data/Data-Download.html

van der Linden, S., A. Janz, B. Waske, M. Eiden, and P. Hostert. 2007. Classifying segmented hyperspectral data from a heterogeneous urban environment using support vector machines. Journal of Applied Remote Sensing 1(1):013543. https:// doi.org/10.1117/1.2813466

Venier, L. A., M. J. Mazerolle, A. Rodgers, K. A. McIlwrick, S. Holmes, and D. Thompson. 2017. Comparison of semiautomated bird song recognition with manual detection of recorded bird song samples. Avian Conservation and Ecology 12(2):2. https://doi. org/10.5751/ACE-01029-120202

Wang, L., J. Lyons, P. Kanehl, and R. Bannerman. 2001. Impacts of urbanization on stream habitat and fish across multiple spatial scales. Environmental Management 28(2):255-266. https://doi. org/10.1007/s0026702409

White, J. H., J. M. Smith, S. D. Bassett, J. L. Brown, and Z. E. Ormsby. 2018. Raptor nesting locations along an urban density gradient in the Great Basin, USA. Urban Ecosystems 21:51-60. https://doi.org/10.1007/s11252-017-0705-y

Wiens, J. D., R. G. Anthony, and E. D. Forsman. 2014. Competitive interactions and resource partitioning between Northern Spotted Owls and Barred Owls in western Oregon. Wildlife Monographs 185(1):1-50. https://doi.org/10.1002/ wmon.1009

Editor-in-Chief: Ryan Norris Subject Editor: Brad Fedy
Sponsored by the Society of Canadian Ornithologists and Bird Studies Canada Parrainée par la Société des ornithologistes du Canada et Études d'oiseaux Canada

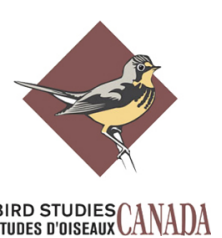


Appendix 1. Pearson correlation coefficient of habitat variables considered to model Barred Owl occupancy in the southern Piedmont. Due to the highly fragmented nature of the study region, none of the habitat characteristics considered were correlated and all were kept in the analysis.

\begin{tabular}{lcccccc}
\hline \hline VARIABLE & WETLAND & STREAM & TREE HEIGHT & DECID & CONIF & IMPERV \\
\hline WETLAND & 1.00 & 0.48 & 0.13 & 0.09 & -0.17 & -0.14 \\
STREAM & 0.48 & 1.00 & 0.02 & 0.35 & -0.09 & -0.22 \\
TREE HEIGHT & 0.13 & 0.02 & 1.00 & 0.14 & -0.01 & -0.26 \\
DECID & 0.09 & 0.35 & 0.14 & 1.00 & 0.05 & -0.38 \\
CONIF & -0.17 & -0.09 & -0.01 & 0.05 & 1.00 & -0.51 \\
IMPERV & -0.14 & -0.22 & -0.26 & -0.38 & -0.51 & 1.00 \\
\hline
\end{tabular}

